\title{
ISOLATION, IDENTIFICATION AND MOLECULAR CHARACTERIZATION OF MULTIDRUG RESISTANT ESCHERICHIA COLI RECOVERED FROM PIGS OF ARUNACHAL PRADESH, INDIA
}

\author{
R. MANDAKINI, T. K. DUTTA*, P. ROYCHOUDHURY, P. K. SUBUDHI \\ I. SAMANTA ${ }^{1}$ AND S. BANDYOPADHAYAY ${ }^{2}$ \\ Department of Veterinary Microbiology \\ College of Veterinary Sciences and Animal Husbandry \\ Central Agricultural University-Imphal, Selesih \\ Aizawl-796 014, Mizoram, India
}

\begin{abstract}
Development and circulation of multidrug resistant (MDR) enteric bacteria is increasingly posing a global threat in the field of therapeutic approaches in human and animals. Information on prevalence of MDR enteric bacteria in pig population is scarce in India in general and in North Eastern hilly states of India in particular. The present study was formulated to understand the prevalence of MDR Escherichia coli in organized and unorganized pig population of Arunachal Pradesh, India with special emphasis on detection of antimicrobial resistance gene profiles of the isolates. A total of 100 fecal samples from pigs of organized $(n=49)$ and unorganized $(n=51)$ farms in Arunachal Pradesh were collected randomly with or without any symptoms of diarrhoea. Samples were processed for isolation and identification of $E$. coli by phenotypic and genotypic methods. All the isolates were subjected to antimicrobial susceptibility assay by disc diffusion method followed by ESBLs production by double discs synergy test (DDST), detection of major ESBLs genes, non-ESBLs genes and integrons by specific PCR assays. A total of 292 E. coli was isolated, of which 155 and 137 were from organized and unorganized farms, respectively. The highest resistance was exhibited by cefalexin $(83.56 \%)$, whereas imipenem $(0.34 \%)$ was recorded with least resistance. Overall, isolates from organized farms showed higher level of resistance against majority of the antimicrobial agents compared to the isolates from unorganized farms. By DDST method, a total of $121(41.44 \%) E$. coli isolates were recorded as ESBLs producer, of which $80(51.61 \%)$ and $41(29.93 \%)$ were from organized and unorganized farms, respectively. A total of $41(14.04 \%), 10(3.42 \%), 15(5.14 \%)$ and $6(2.05 \%)$ isolates were found to be positive for $b^{\prime} a_{T E M}, b l a_{C T X-\mathrm{M}}, b l a_{C M Y}$ and $b l a_{S H V}$ gene, respectively. In addition, $81(27.74 \%), 15(5.14 \%), 75(25.68 \%), 54$ $(18.49 \%), 51(17.46 \%)$ and $15(5.14 \%)$ were found to be positive for tetA, tetB, sull, sul2, aadA and dfrla genes, respectively. A total of $66(22.60 \%)$ isolates were found to be positive for $i n t I 1$, of which $42(14.38 \%)$ and $24(8.22 \%)$ were from organized and unorganized farms, respectively. Class 2 integrons (intI2) were not detected in any of the isolates. MDR E. coli are highly prevalent in pig population of Arunachal Pradesh and isolates from organized farms were more resistant than isolates from unorganized farms. Presence of such kind of MDR bacteria in pig population may pose a serious public health concern.
\end{abstract}

Key words: Arunachal Pradesh, Escherichia coli, India, Multidrug resistant, Pig

*Corresponding Author

${ }^{1}$ Department of Veterinary Microbiology, WBUAFS, 37 Belgachhia Road, Kolkata- 700037

${ }^{2}$ ICAR-Eastern Regional Station of IVRI, 37 Belgachhia Road, Kolkata- 700037 
Problems associated with the development and spread of antibiotic resistance have been increasing since the early 1960 s and are currently viewed as a major threat to global public health (World Health Organization, 2001). The ability of bacteria to acquire and disseminate exogenous genes via mobile genetic elements considered to be the major factor in the development of MDR strains (Rowe-Magnus et al., 2002). At present, the emergence of MDR bacteria is a global public health concern. In organized mass poultry and livestock production facilities, antimicrobial agents may be used for therapeutic and prophylactic purposes or as growth promoters at sub-therapeutic levels (Bacquero et al., 1997), which puts selective pressure on commensals and pathogenic bacteria contributing to clonal expansion of MDR (Bacquero et al., 1997). MDR bacteria can persist in the environment and can transmit the resistance determinants among the other close or distantly related bacteria as well as commensals bacteria. Therefore, there is an urgent need to understand the ecology of those strains and their resistance determinants.

E. coli is common gastrointestinal flora to be capable of accepting and transferring plasmids, which under stress readily transfers it to other species and is, therefore, considered an important reservoir of transferable antibiotic resistance (Lim et al., 2007). The frequency of resistance in E. coli to $\beta$-lactam is increasing worldwide (Kallen et al., 2010). Resistance in E. coli and other Enterobacteriaceae has continuously developed with decreasing susceptibility to first-line antimicrobials, viz., ampicillin, nitrofurantoin, co-trimoxazole as well as the fluoroquinolones like ciprofloxacin and levofloxacin (Sahm et al., 2000). In
Europe, 30 to $50 \%$ clinical isolates are resistant to amoxicillin (Luzzaro et al., 2002) and 6 to $17 \%$ to fluoroquinolones, which is still increasing (Kurt et al., 2008). The huge quantity of inappropriately selected antibiotics is considered the most significant factors for the development of bacterial resistance to antimicrobial drugs (Goossens et al., 2005).

Several scientific articles are citing the role of ESBLs for development of MDR bacteria in man and animals. Moreover, most of the organisms are capable of crossing the species barrier (the so called zoonotic agents) and therefore, becoming a serious threat in treatment of infectious diseases. Although, extensive studies were carried out in USA and Europe, the developing countries are still lagging behind, especially, India. So far prevalence of ESBLs in India has reached in epidemic proportions ranging from $62-100 \%$, of which majority are in E. coli and $K$. pneumoniae isolates (Walsh et al., 2007). Apart from TEM and SHV types, isolates from India additionally produce CTX-M enzymes (Mathai et al., 2009), in which CTX-M-15 appeared to be the predominant ESBLs in Northern India (Walsh et al., 2007). Studies conducted in North Eastern India confirmed the presence of ESBLs ( $b l a_{C T X-M}$ and $\left.b l a_{S H V}\right)$ through isolation of $E$. coli from faecal samples of pigs in different districts of Mizoram (Lalzampuia et al., 2013). An ESBLproducing E. coli possessing bla $a_{C T X-M}$ and $b l a_{S H V}$ associated with human diarrhoea has been reported in India (Dutta et al., 2013). Lalruatdiki (2013) also reported the prevalence ESBL producing genes $\left(\right.$ bla $_{T E M}$, bla $a_{C T X-M}$ and $\left.b l a_{C M Y}\right)$ in the enteric bacteria of pig population in Meghalaya and Assam. Although few sporadic reports are available, no efforts have 
been made till date to detect the MDR enteric bacteria in food animals and their subsequent characterization from Arunachal Pradesh of India. Detailed molecular characterization of multidrug resistant strains largely remains unknown. The present study was undertaken to understand the prevalence of multidrug resistant E. coli in pig population of Arunachal Pradesh and their subsequent characterization.

\section{MATERIALS AND METHODS}

Sample collection: Fresh faecal samples were collected randomly from pigs of Arunachal Pradesh. A total of 100 faecal samples were collected randomly from pigs maintained under organized $(n=49)$ as well as unorganized $(\mathrm{n}=51)$ farming system irrespective age, sex and with or without history of diarrhea during the study. All the samples were collected using a sterilized adsorbent cotton swab. However, for collection of samples from distant locations, a sterilized swab dipped in brain heart infusion broth was used as transport medium and transported to the laboratory under cold chain for further processing.

Isolation and identification of Escherichia coli: The collected faecal samples were processed for isolation and identification of E. coli using standard bacteriological techniques. Five single pure colonies were picked from each inoculated plate for further confirmation. All the isolates were further confirmed by BD Phoenix automated bacterial identification system and 16S rRNA based species specific PCR assay. All the isolates were stored as pure culture in semi-solid agar at $4^{\circ} \mathrm{C}$ as well as in Luria Bertani (LB) Broth containing $25 \%$ glycerol $(\mathrm{v} / \mathrm{v})$ at $-80^{\circ} \mathrm{C}$ for further use.

Antibiotic susceptibility test and confirmatory test for ESBLs: Antimicrobial susceptibility test was done on Mueller-Hinton agar (Hi-media) plate as per the recommendation of Clinical Laboratory Standard Institute (CLSI, 2014) using the following commercially available antibiotic discs: Amoxicillin (Ax, $30 \mathrm{mcg}$ ), Ampicillin (AMP, $10 \mathrm{mcg}$ ), Aztreonam (Az, $30 \mathrm{mcg}$ ), Cefalexin (CN, $30 \mathrm{mcg}$ ), Cefexime (CFM, 30 mcg), Cefotaxime (CTX, $30 \mathrm{mcg}$ ), Ceftazidime (CAZ, $30 \mathrm{mcg}$ ), Ceftriaxone (CTR, $30 \mathrm{mcg}$ ), Ciprofloxacin (CIP, $5 \mathrm{mcg}$ ), Co-Trimoxazole (COT, 1.25/23.75 mcg), Gentamicin (GEN, 10mcg), Imipenem (IPM, $10 \mathrm{mcg}$ ), Nalidixic acid (NA, $30 \mathrm{mcg}$ ), Piperacillin (PI, $100 \mathrm{mcg}$ ), Streptomycin (S, $10 \mathrm{mcg}$ ), Sulphafurazole/sulfisoxazole (SF, $300 \mathrm{mcg}$ ), Tetracycline (TE, $30 \mathrm{mcg}$ ) and Trimethoprim (TR, $30 \mathrm{mcg}$ ). Isolates exhibited inhibition zone of $\leq 22 \mathrm{~mm}$ for ceftazidine $(30 \mu \mathrm{g}), \leq 25 \mathrm{~mm}$ for ceftriazone $(30 \mu \mathrm{g})$ and $\leq 27 \mathrm{~mm}$ for cefotaxime $(30 \mu \mathrm{g})$ were identified as potential ESBLs producer.

Confirmatory test for ESBLs production was carried out using cefotaxime $(30 \mathrm{mcg})$, amoxicillin $(30 \mathrm{mcg})$ and ceftazidime $(30 \mathrm{mcg})$ alone as well as cefotaxime/clavulanate (30/10 $\mathrm{mcg})$, amoxicillin/clavulanate $(30 / 10 \mathrm{mcg})$ and ceftazidime/clavulanate $(30 / 10 \mathrm{mcg})$ combination as per the recommendation of CLSI (2014). Both the discs were placed at least $25 \mathrm{~mm}$ apart, centre to centre, on a lawn culture of the test isolate in Mueller-Hinton agar plate and incubated overnight at $37^{\circ} \mathrm{C}$. Difference in zone diameters with and without clavulanic acid was measured. When there was an increase of $\geqslant 5 \mathrm{~mm}$ in inhibition zone diameter around antimicrobial agent tested in combination with clavulanic acid versus its inhibition diameter zone when tested alone was confirmed as potent ESBLs producing isolates.

Genotypic detection of antibiotic resistance profile: Presence of antimicrobial resistance 
Table 1. Details of the oligonucleotide primers used in the present study

\begin{tabular}{|c|c|c|c|c|}
\hline $\begin{array}{l}\text { Primer } \\
\text { name }\end{array}$ & Sequence $\left(5^{\prime} \rightarrow 3^{\prime}\right)$ & $\begin{array}{l}\text { Expected } \\
\text { amplicon } \\
\text { size (bp) }\end{array}$ & $\begin{array}{c}\text { Annealing } \\
\text { temperature } \\
\left({ }^{\circ} \mathbf{C}\right)\end{array}$ & Reference \\
\hline$b l a_{T E M}$ & $\begin{array}{l}\text { ATAAAATTCTTGAAGACGAAA } \\
\text { GACAGTTACCAATGCTTAATC }\end{array}$ & 1080 & 53 & Weill et al., 2004 \\
\hline$b l a_{S H V}$ & $\begin{array}{l}\text { CTTTCCCATGATGAGCACCT } \\
\text { CGCTGTTATCGCTCATGGTA }\end{array}$ & 206 & 60 & This study \\
\hline$b l a_{C T X-M}$ & $\begin{array}{l}\text { CAATGTGCAGCACCAGTAA } \\
\text { CGCGATATCGTTGGTGGTG }\end{array}$ & 540 & 58 & $\begin{array}{l}\text { Perez and } \\
\text { Hanson, } 2002\end{array}$ \\
\hline$b l a_{C M Y}$ & $\begin{array}{l}\text { TGGCCAGAACTGACAGGCAAA } \\
\text { TTTCTCCTGAACGTGGCTGGC }\end{array}$ & 462 & 60 & $\begin{array}{l}\text { Perez and } \\
\text { Hanson, } 2002\end{array}$ \\
\hline tet $A$ & $\begin{array}{l}\text { GTAATTCTGAGCACTGTCGCT } \\
\text { CTGCCTGGACAACATTGCT }\end{array}$ & 937 & 57 & $\begin{array}{l}\text { Guardabassi } \\
\text { et al., } 2000\end{array}$ \\
\hline tetB & $\begin{array}{l}\text { TTGGTTAGGGGCAAGTTTTG } \\
\text { GTAATGGGCCAATAACACCG }\end{array}$ & 659 & 57 & $\begin{array}{l}\text { Fonseca } \\
\text { et al., } 2006\end{array}$ \\
\hline Sull & $\begin{array}{l}\text { TGGTGACGGTGTTCGGCATTC } \\
\text { GCGAGGGTTTCCGAGAAGGTG }\end{array}$ & 789 & 63 & $\begin{array}{l}\text { Mazel } \\
\text { et al., } 2000\end{array}$ \\
\hline Sul2 & $\begin{array}{l}\text { CGGCATCGTCAACATAACC } \\
\text { GTGTGCGGATGAAGTCAG }\end{array}$ & 722 & 58 & $\begin{array}{l}\text { Maynard } \\
\text { et al., } 2003\end{array}$ \\
\hline$A a d A$ & $\begin{array}{l}\text { GCAGCGCAATGACATTCTTG } \\
\text { ATCCTTCGGCGCGATTTTG }\end{array}$ & 282 & 58 & $\begin{array}{l}\text { Madsen } \\
\text { et al., } 2000\end{array}$ \\
\hline DfrIa & $\begin{array}{l}\text { GTGAAACTATCACTAATGG } \\
\text { TTAACCCTTTTGCCAGATTT }\end{array}$ & 474 & 53 & Navia, 2003 \\
\hline IntII & $\begin{array}{l}\text { GGGTCAAGGATCTGGATTTCG } \\
\text { ACATGGGTGTAAATCATCGTC }\end{array}$ & 483 & 60 & $\begin{array}{l}\text { Mazel } \\
\text { et al., } 2000\end{array}$ \\
\hline IntI2 & $\begin{array}{l}\text { CACGGATATGCGACAAAAAGGT } \\
\text { GTAGCAAACGAGTGACGAAATG }\end{array}$ & 788 & 60 & $\begin{array}{l}\text { Mazel } \\
\text { et al., } 2000\end{array}$ \\
\hline $\begin{array}{l}5^{\prime}-\mathrm{CS} \\
3^{\prime}-\mathrm{CS}\end{array}$ & $\begin{array}{l}\text { GGCATACAAGCAGCAAGC } \\
\text { AAGCAGACTTGACCTGAT }\end{array}$ & variable & 52 & $\begin{array}{l}\text { Zhang et al., } \\
2004\end{array}$ \\
\hline $\begin{array}{l}\text { Ti-F } \\
\text { Ti-B }\end{array}$ & $\begin{array}{l}\text { ACCTTTTTGTCGCATATCCGTG } \\
\text { CTAACGCTTGAGTTAAGCC }\end{array}$ & variable & 55 & Su et al., 2006 \\
\hline
\end{tabular}

(AMR) genes was analysed by PCR using bacterial lysate as template DNA. Detection of AMR genes were performed for sulfamethoxazole resistant isolates ( $\mathrm{Sul}$ and Sul2), ampicillin resistance isolates (blaTEM,
blaSHV, blaCTX-M and blaCMY), tetracycline resistant isolates $(\operatorname{Tet} A)$, streptomycin resistant isolates $(\operatorname{aadA})$ and trimethoprim resistant isolates (dfrla) using specific oligonucleotide primers (Table-1). PCR conditions were 
followed as per the method described by Nazik et al. (2011) with suitable modifications. The repeatability of the assay was checked by repeating the PCR for three times.

\section{Detection of antibiotic resistance integrons:} The MDR isolates were also screened for the presence of class 1 and 2 integrons, viz., intII and int 12 as well as its gene cassettes 5CS/3CS and TiB/TiF. PCR amplification was used to detect class 1 and class 2 integrase genes (intII and intI2 respectively) using specific primers (Table-1). The condition used for amplification of the two integrase genes were as follows: initial denaturation at $94^{\circ} \mathrm{C}$ for $5 \mathrm{~min}, 30$ amplification cycles consisting of $50 \mathrm{sec}$ at $94^{\circ} \mathrm{C}, 50 \mathrm{sec}$ at $60^{\circ} \mathrm{C}$ and $1 \mathrm{~min}$ at $72^{\circ} \mathrm{C}$ and final extension for $6 \mathrm{~min}$. Amplification of variable region of class 1 and class 2 integrons were performed using the primers $52-\mathrm{CS} / 32-\mathrm{CS}$ and Ti-F/Ti-B, as per the conditions and procedures described previously by Zhang et al. (2004).

\section{RESULTS}

Isolation of $\boldsymbol{E}$. coli: A total of 292 E. coli was isolated, of which 155 and 137 were from organized and unorganized farms, respectively.

Antibiotic susceptibility of the isolates: Amongst the 292 isolates obtained from both organized and unorganized farms of Arunachal Pradesh, imipenem $(99.66 \%)$ was found to be the most sensitive antibiotic, which was followed by ceftriaxone $(96.23 \%)$, cefotaxime $(90.75 \%)$, streptomycin $(89.04 \%)$, nalidixic acid $(84.59 \%)$, co-trimoxazole $(82.19 \%)$, trimethoprime $(81.85 \%)$, ceftazidime $(81.51 \%)$, ampicillin $(79.79 \%)$, tetracycline $(77.74 \%)$, gentamicin $(75.00 \%)$, aztreonam $(70.21 \%)$, cefexime $(60.62 \%)$, sulphafurazole
$(54.45 \%)$, piperacillin $(51.71 \%)$, amoxicillin $(21.58 \%)$ and cefalexin (16.44\%). Conversely, the maximum level of resistance was exhibited by cefalexin $(83.56 \%)$ and imipenem $(0.34 \%)$ was recorded with least level of resistance (Table 2).

As depicted in (Table 2), all the 155 isolates from organized farms of Arunachal Pradesh showed $100.00 \%$ sensitivity to imipenem but lowest sensitivity to cefalexin $(10.32 \%)$. On the other hand, the isolates showed maximum level of resistance to cefalexin $(89.68 \%)$ followed by amoxicillin (70.97\%), piperacillin $(60.65 \%)$, aztreonam $(46.45 \%)$, cefexime $(42.58 \%)$, sulphafurazole $(41.29 \%)$, tetracycline $(32.26 \%)$, gentamicin $(25.81 \%)$, trimethoprim (19.35\%), streptomycin (18.71\%), co-trimoxazole (17.42\%), ampicillin $(12.90 \%)$, nalidixic acid $(10.97 \%)$, ceftazidime $(9.68 \%)$ and cefotaxime $(3.23 \%)$.

Similarly, all the 137 isolates from unorganized farms of Arunachal Pradesh, highest level of sensitivity was observed against imipenem $(99.27 \%)$ and lowest level of sensitivity was exhibited by amoxicillin (13.14\%) (Table 2). Conversely, the maximum level of resistance was recorded against amoxicillin $(86.86 \%)$ followed by cefalexin (76.64\%), sulphafurazole $(50.36 \%)$, cefexime $(35.77 \%)$, piperacillin $(34.31 \%)$, ampicillin $(28.47 \%)$, ceftazidime (28.47\%), gentamicin (24.09\%), nalidixic acid (20.44\%), co-trimoxazole (18.25\%), cefotaxime $(16.06 \%)$, trimethoprim $(16.79 \%)$, aztreonam (10.95\%), tetracycline $(10.95 \%)$, ceftriaxone (5.84\%), streptomycin (2.19\%), ciprofloxacin $(1.46 \%)$ and imipenem $(0.73 \%)$.

By DDST method, a total of $121(41.44 \%)$ E. coli isolates were recorded as ESBLs producer, of which $80(51.61 \%)$ and 41 $(29.93 \%)$ were from organized and unorganized farms, respectively. 
Table 3. Details of detection of MDR E. coli isolated from faecal samples of pigs from organized and unorganized farms of Arunachal Pradesh, India

\begin{tabular}{lcccc}
\hline \multicolumn{1}{c}{ Antibiotics } & $\begin{array}{c}\text { Organized } \\
\text { farm }\end{array}$ & $\begin{array}{c}\text { Unorganized } \\
\text { farm }\end{array}$ & Total & ND value \\
\hline Amoxicillin & $110(70.97)$ & $119(86.86)$ & $229(78.42)$ & $3.29^{* *}$ \\
Ampicillin & $20(12.90)$ & $39(28.47)$ & $59(20.205)$ & $3.31^{* *}$ \\
Aztreonam & $72(46.45)$ & $15(10.95)$ & $87(29.795)$ & $6.62^{* *}$ \\
Cefalexin & $139(89.68)$ & $105(76.64)$ & $244(83.562)$ & $3^{* *}$ \\
Cefexime & $66(42.58)$ & $49(35.77)$ & $115(39.384)$ & $1.19^{\mathrm{NS}}$ \\
Cefotaxim & $5(3.23)$ & $22(16.06)$ & $27(9.247)$ & $3.78^{* *}$ \\
Ceftazidime & $15(9.68)$ & $39(28.47)$ & $54(18.493)$ & $4.13^{* *}$ \\
Ceftriaxone & $3(1.94)$ & $8(5.84)$ & $11(3.767)$ & $1.75^{\mathrm{NS}}$ \\
Ciprofloxacin & $1(0.65)$ & $2(1.46)$ & $3(1.027)$ & $0.69^{\mathrm{NS}}$ \\
Co-Trimoxazole & $27(17.42)$ & $25(18.25)$ & $52(17.993)$ & $0.16^{\mathrm{NS}}$ \\
Gentamicin & $40(25.81)$ & $33(24.09)$ & $73(25.000)$ & $0.34^{\mathrm{NS}}$ \\
Imipenem & $0(0.00)$ & $1(0.73)$ & $1(0.342)$ & $1.07^{\mathrm{NS}}$ \\
Nalidixic acid & $17(10.97)$ & $28(20.44)$ & $45(15.411)$ & $2.24^{*}$ \\
Piperacillin & $94(60.65)$ & $47(34.31)$ & $141(48.288)$ & $4.5^{* *}$ \\
Streptomycin & $29(18.71)$ & $3(2.19)$ & $32(10.959)$ & $4.51^{* *}$ \\
Sulphafurazole & $64(41.29)$ & $69(50.36)$ & $133(45.548)$ & $0.38^{\mathrm{NS}}$ \\
Tetracycline & $50(32.26)$ & $15(10.95)$ & $65(22.260)$ & $4.37^{* *}$ \\
Trimethoprim & $30(19.35)$ & $23(16.79)$ & $53(18.151)$ & $0.57^{\mathrm{NS}}$ \\
\hline
\end{tabular}

*Statistically significant $(\mathrm{P}<0.05)$ between organized and unorganized farm; **Highly significant $(\mathrm{P}<0.01)$ between organized and unorganized farm; ${ }^{\text {NS}}$ Not significantly different between organized and unorganized farm. Figures in parentheses indicate percentages

Statistical analysis showed that the level of resistance against amoxicillin, ampicillin, aztreonam, cefalexin, cefotaxime, ceftazidime, piperacillin, streptomycin and tetracycline differed significantly $(\mathrm{P}>0.01)$ between the organized and unorganized farms of Arunachal Pradesh. The resistance level against nalidixic acid was also differing significantly $(\mathrm{P}>0.05)$ between the organized and unorganized farms. However, no significant difference was observed in the level of resistance against the remaining antimicrobial agents (Table 3 ).

Genotypic detection of beta-lactamase genes: Amongst all the $E$. coli isolates from Arunachal Pradesh, 41 (14.04\%) were found to be positive for $b l a_{T E M}$ gene. Likewise, a total of $10(3.42 \%)$ isolates were found positive for $b l a_{C T X-\mathrm{M}}$ genes. In the case of bla $a_{C M Y}$ gene, a total of $15(5.14 \%)$ isolates were recorded as positive. A total of 6 


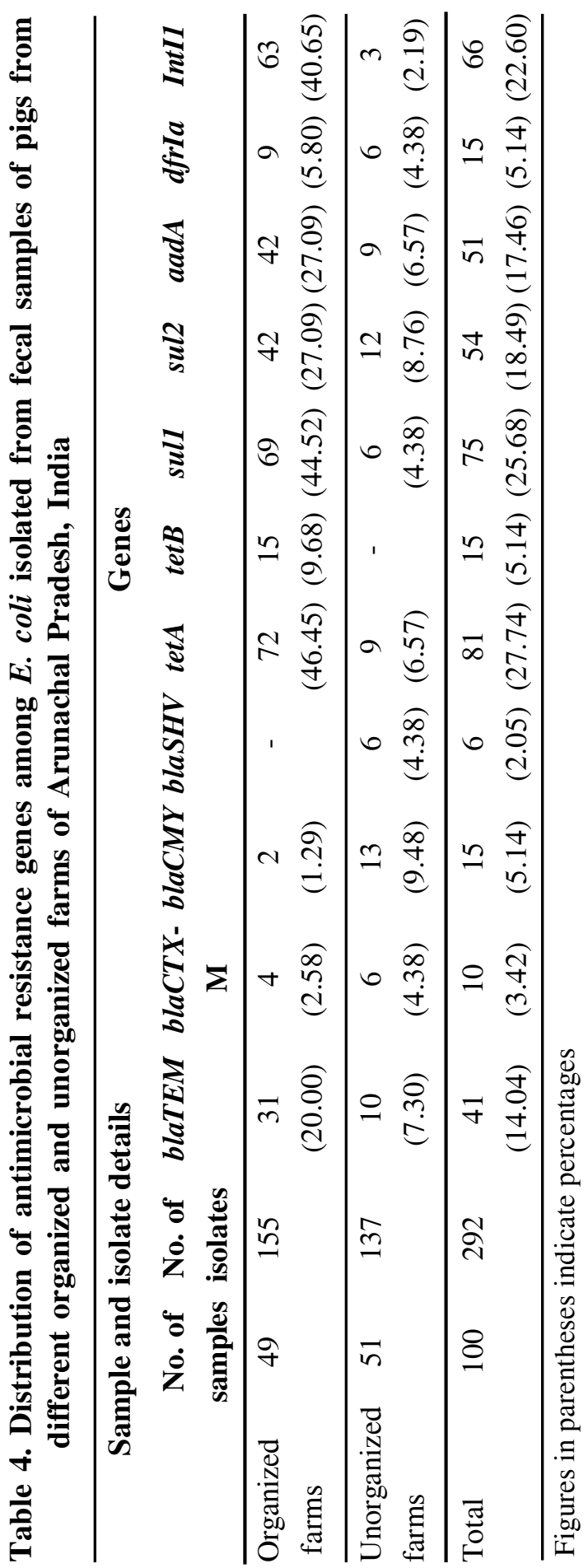

$(2.05 \%)$ isolates were recorded as positive for $b l a_{S H V}$ genes.

Among the isolates from organized farms, $31(20.00 \%)$ were positive for bla $a_{T E M}$, whereas, bla $a_{C T X-M}$ and bla $a_{C M Y}$ were detected in $4(2.58 \%)$ and $2(1.29 \%)$ isolates, respectively. bla $a_{S H V}$ gene was not detected in any of the isolates. Similarly, from the unorganized farms, 13 (9.48\%), 10 (7.30\%), $6(4.38 \%)$ and $6(4.38 \%)$ isolates were found as positive for $b l a_{C M Y}, b l a_{T E M}, b l a_{C T X-M}$ and $b l a_{S H V}$ genes, respectively (Table 4)

Genotypic characterization of Non-ESBLs genes: In Arunachal Pradesh, of the 292 isolates from both organized and unorganized farms, $81(27.74 \%), 15$ (5.14\%), 75 (25.68\%), 54 (18.49\%), 51 $(17.46 \%)$ and $15(5.14 \%)$ were found to be positive for tetA, tetB, sull, sul2, aadA and $d f r l a$ genes, respectively. Amongst the isolates from the organized farms, 72 (46.45\%), 15 (9.68\%), 69 (44.52\%), 42 (27.09\%), $42(27.09 \%)$ and $9(5.80 \%)$ were positive for tetA, tetB, sull, sul2, aadA and $d f r l a$ genes, respectively. On the other hand, amongst the isolates from the unorganized farms, only $9(6.57 \%), 6(4.38 \%), 12$ $(8.76 \%), 9(6.57 \%)$ and $6(4.38 \%)$ were positive for tetA, sul1, sul2, aadA and dfrla genes, respectively. No isolates were found to be positive for tet $B$ gene(Table 4)

Detection of antibiotic resistance Integrons and gene cassettes: In the present study, a total of $66(22.60 \%)$ E. coli isolates were found to be positive for Class 1 integrons (intI1), of which $42(14.38 \%)$ were from organized farms and $24(8.22 \%)$ were from unorganized farms. However, Class 2 integrons (intI2) were not detected in any of the isolates. 


\section{DISCUSSION}

In India, the information regarding ESBLs producing enteric bacteria in animal population is very limited. A very limited study has been done in this laboratory on prevalence of ESBLs producing enteric bacteria in man and animals in Mizoram state only. But the data from other parts of the country including NER remains unexplored. Therefore, the present study was conducted to investigate the prevalence of ESBLs producing E. coli isolates from pigs of Arunachal Pradesh in India with the broad objectives to improve the practice of antimicrobial's use in clinical practice, farm biosecurity, epidemiological studies and also safeguarding against the zoonotic outbreaks by MDR bacteria in human and animal population.

In the present study, a total of 292 E. coli were isolated and identified from 100 faecal samples collected from pigs of organized and unorganized farms of Arunachal Pradesh in India with or without the history of diarrhoea. E. coli is a commensal in the intestinal tract of man and animals. The population in the gut may vary depending upon the physiological and/or pathological status of the host. A similar or little variable rate of $E$. coli isolation from various animals is reported from India and abroad. Earlier, from the same laboratory, Lalzampuia (2012) isolated $102 \mathrm{E}$. coli from 53 faecal samples collected from pigs of different districts of Mizoram. On the other hand, Lalruatdiki (2013) isolated 867 E. coli from 228 fecal samples collected from Meghalaya and Assam. In another study, Wani et al. (2003) reported $249 \mathrm{E}$. coli from 391 bovine and 60 E. coli from 101 ovine faecal samples in
Srinagar, Jammu \& Kashmir. But from the same laboratory, Bhat et al. (2008) isolated 284 E. coli from 236 samples from lambs with or without diarrhoea. The rate of isolations of $E$. coli from faecal samples may vary depending upon the nature of samples, types of media used, laboratory practices of the researchers, treatment status of the host and so on. Number of E. coli colonies picked up from a particular sample is also variable. It may lead to variation in the frequency of E. coli isolates from a particular number of samples. In this study, a minimum of 5 suspected colonies were picked up randomly from primary culture plate for further confirmation by morphological and biochemical characteristics. All the isolates obtained in this study revealed typical biochemical and cultural characteristics as mentioned by Ewing (1986). No isolates exhibited any atypical biochemical or cultural properties in the laboratory.

Antimicrobial resistance is a very complex phenomenon involving a large variety of antimicrobial agents, bacterial species, resistance genes and mechanism of resistance. Different countries in the world use different antibiotics for treatment of same kind of infections. In this regard, $\beta$-lactam antibiotics are widely used for treatment of infectious diseases in human and animals. Many pathogenic organisms encoding multiple antibiotic resistance genes are increasing day by day throughout the world (Perez et al., 2007). In this study, all the isolates showed resistance to at least three antimicrobial agents; majority was multi-resistant. The resistance pattern of $E$. coli isolates against all the antimicrobial agents are variable within the isolates obtained from different 
farms of the state. In this study, the resistance pattern of $E$. coli isolates against all the four third generation cephalosporins showed variable resistance. The NARMS report also mentioned that resistance to ceftriaxone was ranging from $6.3-13.5 \%$ among the $E$. coli recovered from chickens during 2000-2008. In contrast to our result, Sasirekha et al. (2010) reported that $84 \%, 75 \%$ and $85 \% E$. coli were resistant to cefotaxime, ceftriaxone and ceftazidime, respectively. On the other hand, Rosengren et al. (2008) reported no resistant isolates against ceftriaxone and less than $1 \%$ resistant to cefoxitin and ceftiofur. Resistant strains were isolated from the pigs in the production system that used beta-lactam antimicrobials including tetracycline class more often than from pigs in another type of large production system (Gebreyes et al., 2004).

In the present study, the level of resistance against streptomycin and tetracycline is significantly low in case of unorganized farms compared to the organized farms of Arunachal Pradesh, which may be due to less usage of these drugs by backyard farmers in this state. We could not compare our data on antibiotic resistance in pigs with different farming practices because of nonavailability of similar information in this region. A relatively low frequency of resistance was also observed against gentamicin, nalidixic acid and ciprofloxacin (Table 2). In a retrospective study on antimicrobial drug resistance in Escherichia coli from humans and food animals, United States, 1950-2002, Tadesse et al. (2012) stated that tetracycline resistance was the most common type of resistance observed and the most prevalent resistance phenotype in animal isolates $(71.1 \%)$. This finding was not surprising because tetracycline has been widely used in therapy and to promote feed efficiency in animal production systems since its approval in 1948. Persistence of tetracycline resistance was reported in animal coliforms a decade after it was no longer used in feed or for treatment. We commonly found co-resistance for tetracycline with streptomycin, sulfonamide, ampicillin, and chloramphenicol, as in other studies. A pan-European monitoring study on susceptibility to human-use antimicrobial agents in enteric bacteria isolated from healthy food producing animals (de Jong et $a l ., 2012$ ) specifically pointed out the relationship of antimicrobials used and development of resistance. The food animals including pigs showed very low level of resistance against the older antimicrobials, which are not very frequently in use for human or veterinary practices. With the availability of third and fourth generation of cephalosporins and without any restriction upon their use in veterinary and human health practice in this country, a high level of resistance against them are increasingly evidenced. At the same time, a decrease in level of resistance against older antimicrobials is also evidenced. Although, some antimicrobial agents are not in use for veterinary practices in India, a high level of resistance against them is recorded in the fecal E. coli of swine. The persistence of resistance might result from the process of co-selection by other antimicrobials being used in pigs (Binch et al., 2008). This occurs when genes encoding for these antimicrobials are linked with those encoding for other antimicrobials being used (Witte, 1998). Another pathway for 
persistence of antimicrobial resistance is the linkage of chromosomally located antimicrobial resistance genes that are not readily lost by bacteria (Holzel et al., 2010). Most of the ESBL producing organisms were co-resistant to flouroquinolones, aminoglycosides and co-trimoxazole, which corroborates with the study of various other workers (Denholm et al., 2009; Jabeen et al., 2005). A nearly similar kind of information, where the ESBLs producing enteric bacteria was also recorded as resistant to other group of antibiotics (Perez et al., 2007). Development of such co-resistance against other classes of antibiotics including â-lactam antibiotics by the ESBLs producing organisms generally appeared in the large plasmids, where most of the resistance genes may co-exist.

Antimicrobial resistance in commensal Enterobacteriaceae from pigs may play an important role in the ecology of resistance, constituting an important reservoir for these transmissible resistance genes. In this study, isolates from organized farms showed highest prevalence of $b l a_{C T X-M}$ gene and least $(0.46 \%)$ prevalence of $b l a_{C T X-M}$ gene. In case of unorganized farms, $E$. coli isolates recorded highest prevalence of $b l a_{C T X-M}$. In this regard, our result is in corroboration with the report of other workers from abroad except one report from this laboratory. In a small scale study, Lalzampuia et al. (2013) reported that $7(5.07 \%)$ and $3(2.17 \%) E$. coli isolated from pigs of Mizoram were positive for bla $a_{C T X-\mathrm{M}-1}$ and $b l a_{T E M}$ gene, respectively, of which $3(2.17 \%)$ isolates were positive for both the genes. Only 4 (2.90\%) isolates carried bla $a_{C T X-M-I}$ gene alone.
Globally, the prevalence of $C T X-M$ producing $E$. coli is varied between $0.8 \%$ in Europe to $3.4 \%$ in Western Pacific region as reported by Winokur et al. (2001). Li et al. (2005) reported $1.5 \%$ CTX-M producing Salmonella spp. in Taiwan. In contrast to our result, several workers from India and abroad reported a higher prevalence of $C T X-M$ gene in enteric bacteria of human and animals (Adeleke et al., 2012; Senthilkumaran, 2012). The variation of results in this study in comparison to the other reports may be due to lower expression of $C T X-M$ genes. $b l a_{C T X-\mathrm{M}}$ genes spread in the community mostly through the transmission of plasmids. It is also reported that animals may play as possible role for the dissemination to humans (Faure et al., 2009). Indeed, from the same laboratory bla $a_{C T X-\mathrm{M}}$ genes in E. coli from human and animals from Mizoram is already published (Dutta et al., 2013; Lalzampuia et al., 2013). These observations suggest the possibility of transfer of extended-spectrum cephalosporin resistance between animals and humans.

In the present study, the tetracycline resistance gene tet $A$ was detected most frequently in organized farms, which is also in agreement with the study carried out on E. coli isolated from healthy pigs from various places of the world (JuradoRabadán et al., 2014). The presence of tet genes has been reported as a prevailing mechanism for tetracycline resistance in $E$. coli isolates from pet animals and wild animals. In general, tetracycline resistance develops due to acquisition of genes involved mainly in three processes: antibiotic efflux through energy-dependent membrane associated proteins, ribosomal protection 
and enzymatic inactivation of tetracycline.

Class 1 integrons are the most common antibiotic resistant genes found in the clinical isolates of gram-negative bacteria. Su et al. (2006) also reported the detection of three classes of integrons in 111 clinical isolates of $E$. coli, of which $85.6 \%$ and $3.6 \%$ of the isolates carried class 1 and class 2 integrons, respectively. Integrons are considered as a primary source of resistance genes and also are considered as reservoirs of antimicrobial resistance genes within microbial populations. Class1 integron was observed in $43 \% \mathrm{E}$. coli strains recovered from animals and humans, while the class 2 integrons was recorded in only $1 \%$ isolated (Van EssenZandbergen et al., 2007). Similarly, Goldstein et al. (2001) reported that $61.5 \%$ of Salmonella spp. isolated from poultry was positive for class 1 integron and only $4.6 \%$ were positive for class 2 integron. As far as

\section{REFERENCES}

Adeleke OE, Onyenwe NE and Mbata TL, 2012. Detection of $b l a_{C T X-M}$ gene on resistant Salmonella enterica from a hospital in Southeast Nigeria. Intl J Biochem Biotech, 1: 162-166

Bacquero F, Negri C, Morosini MI and Blazquez J, 1997. The antibiotic selective process: Concentration-specific amplification of low-level populations. Ciba Foundation Symposium, 207: 93-105

Bhat MA, Nishikawa Y and Wani SA, 2008. Prevalence and virulence gene profiles of Shiga toxin producing Escherichia coli and enteropathogenic Escherichia coli from diarrhoeic and healthy lambs in India. Small Rum Res, 75: 65-70 pig is concerned, Gebreyes and Thakur (2005) reported that out of the 28 isolates, 21 were multidrug resistant and all of them harboured the class 1 integron. Integron gene sequences contribute to the spread of antimicrobial resistance alleles by lateral gene transfer of gene cassettes in a variety of enteric bacteria including Campylobacter spp., Escherichia coli and Salmonella enterica sub sp. enterica serotype Typhimurium (Roe et al., 2003). This finding suggests that the isolates with multiple ESBL genotypes have a greater opportunity to carry class 1 integron. Therefore, bacteria carrying both integrons and ESBL genes have much stronger multiresistance activity. However, the location of ESBL genes in class 1 element was not studied and needs further investigation.

Competing interest: Authors have declared that no competing interests exist.

Binch CTT, Heuer H, Kaupenjohann M and Smalla K, 2008. Piggery manure used for soil fertilization is a reservoir for transferable antibiotic resistance plasmids. FEMS Microbiol Ecol, 66: 25-37

CLSI, 2014. Performance standard for antimicrobial susceptibility testing. 18th Informational Supplement. CLSI Document M100-S18 Wayne, PA

de Jong A, Thomas V, Simjee S, Godinho K, Schiessl B et al., 2012. Pan-European monitoring of susceptibility to human-use antimicrobial agents in enteric bacteria isolated from healthy food-producing animals. J Antimicrob Chemother, 67(3): 638-651 
Denholm JT, Huysmans M and Spelman D, 2009. Community acquisition of ESBL-producing Escherichia coli: a growing concern. Med J Australia, 190: 45-46

Dutta TK, Warjri I, Roychoudhury P, Lalzampuia H, Samanta I et al., 2013. Extended- Spectrum $\beta$ - Lactamase producing Escherichia coli isolate possessing the Shiga Toxin Gene (stx1) belonging to the O64 serogroup associated with human disease in India. J Clin Microbiol, 51: 2008-2009

Ewing WH, 1986. Edward and Ewing's Identification of Enterobacteriaceae, 4th edn., New York: Elsevier

Faure S, Guyomard AP, Delmas JM and Laurentie M, 2009. Impact of therapeutic treatment with $\beta$-lactum on transfer of the bla $a_{\text {CTX-M-9 }}$ resistance gene from Salmonella enteric serovar Virchow to Escherichia coli in gnotobiotic rats. Appl Env Microbiol, 75: 5523-5528

Fonseca EL, Mykytczuk OL, Asensi MD, Reis EMF, Ferraz LR et al., 2006. Clonality and antimicrobial resistance gene profiles of multidrug-resistant Salmonella enterica serovar infantis isolates from four public hospitals in Rio de Janeiro, Brazil. J Clin Microbiol, 44: 2767-2772

Gebreyes WA and Thakur S, 2005. Multidrugresistant Salmonella enterica serovar Muenchen from pigs and humans and potential interserovar transfer of antimicrobial resistance. Antimicrob Agents Chemother, 49: 503-511

Gebreyes WA, Thakur S, Davies PR, Funk JA and Altier, 2004. Trends in antimicrobial resistance phage types and integrons in
Salmonella serotypes from pigs. J Antimicrob Chemother, 53: 997-1003

Goldstein C, Lee MD, Sanchez S, Hudson C, Phillips $\mathrm{B}$ et al., 2001. Incidence of class 1 and 2 integrases in clinical and com-mensal bacteria from livestock, companion animals, and exot-ics. Antimicrob Agents Chemother, 45: 723-736

Goossens H, Ferech M, Vander SR and Elseviers M, 2005. M. ESAC Project Group. Outpatient antibiotic use in Europe and association with resistance: a cross-national database study. Lancet, 365: 579-587

Guardabassi L, Dijkshoorn L, Collard JM, Olsen JE and Dalsgaard A, 2000. Distribution and invitro transfer of tetracycline resistance determinants in clinical and aquatic Acinetobacter strains. J Med Microbiol, 49: 929-936

Hölzel CS, Harms KS, Küchenhoff H, Kunz A, Mu ller C et al., 2010. Phenotypic and genotypic bacterial antimicrobial resistance in liquid pig manure is variously associated with contents of tetracyclines and sulfonamides. J Appl Microbiol, 108: 1642-1656

Jabeen K, Zafar A and Hasan R, 2005. Frequency and sensitivity pattern of extended spectrum beta-lactamase producing isolates in a tertiary care hospital laboratory of Pakistan. J Pakistan Med Assoc, 55: 436-439

Jurado-Rabadán S, de la Fuente R, Ruiz-SantaQuiteria JA, Orden JA, de Vries LE et al., 2014. Detection and linkage to mobile genetic elements of tetracycline resistance gene tet $(M)$ in Escherichia coli isolates from pigs. BMC Vet Res, 10: 1-7

Kallen R, Skurnik D, Pier GB, Andremont A, 
Szmigielska A et al., 2010. Antibiotic prophylaxis and recurrent urinary tract infection in children. New England J Med, 362: $555-556$

Kurt G, Naber A, Giancarlo SB, Henry BC, Juan PD et al., 2008. Surveillance study in Europe and Brazil on clinical aspects and antimicrobial resistance epidemiology in females with cystitis (ARESC): Implications for empiric therapy. European Urol, 54: $1164-1178$

Lalruatdiki A, 2013. Studies on detection and characterisation of extended spectrum betalactamases (esbls) with special reference to bla $_{T E M}$ bla ${ }_{S H,}$ bla ${ }_{C T X-M}$ and bla $a_{C M Y}$ genes in Escherichia coli, Salmonella spp. and Klebsiella pneumoniae isolated from pigs of Meghalaya and Assam. M.V.Sc. thesis, Central Agricultural University, Selesih, Aizawl, Mizoram

Lalzampuia, 2012. Studies on detection and characterisation of extended spectrum $\beta$ lactamases (esbls) with special reference to $b_{\text {bTX-M }}$ and $b l a_{\text {TEM }}$ genes in Escherichia coli, Salmonella spp. and Klebsiella pneumoniae isolated from pig and poultry in Mizoram. M.V.Sc. thesis, Central Agricultural University, Selesih, Aizawl, Mizoram

Lalzampuia H, Dutta TK, Warjri I and Chandra R, 2013. PCR based detection of extended spectrum beta-lactamases ( $b l a_{\text {СтХ-м }}$ and bla $\left.a_{\mathrm{TEM}}\right)$ in Escherichia coli, Salmonella spp. and Klebsiella pneumoniae isolated from pigs in North Eastern India (Mizoram). Indian J Microbiol, doi: 10.1007/s12088013-0378

Li W, Huang FY, Liu CP, Weng LC, Weng LC et al., 2005. Ceftriaxone resistant of non-typhoidal Salmonella enterica isolates in Northern
Taiwan attributable to production of $C T X$ $M-14$ and $C M Y-2 \beta$-lactamases. J Clini Microbiol, 43: 3237-3243

Lim SK, Lee HS, Nam HM, Cho YS, Kim JM et al., 2007. Antimicrobial resistance observed in Escherichia coli strains isolated from fecal samples of cattle and pigs in Korea during 2003-2004. Int J Food Microbiol, 116: 283-286

Luzzaro F, Vigano EF, Fossati D, Grossi A, Sala A et al., 2002. Prevalence and drug susceptibility of pathogens causing bloodstream infections in northern Italy: A two-year study in 16 hospitals. European J Clin Microbiol Infect Dis, 21: 849-855

Madsen LF, Aarestrup M and Olsen JE, 2000. Characterisation of streptomycin resistance determinants in Danish isolates of Salmonella typhimurium. Vet Microbiol, 75: 73-82

Mathai D, Manoharan A and Vasanthan G, 2009. Epidemiology and implications of ESBL. Critc Care Update, 14: 152-162

Maynard C, Fairbrother JM, Bekal S, Sanschagrin F, Levesque RC et al., 2003. Antimicrobial resistance genes in enterotoxigenic Escherichia coli 0149:K91 isolates obtained over a 23-year period from pigs. Antimicrob Agents Chemother, 47: 32143221

Mazel D, Dychinco B, Webb VA and Davies J, 2000. Antibiotic resistance in the ECOR collection: integrons and identification of a novel aad gene. Antimicrob Agents Chemother, 44: 1568-1574

Navia MM, Ruiz J, Sa'nchez-Ce'spedes J and Vila J, 2003. Detection of dihydrofolate reductase genes by PCR and RFLP. Diagn Microb Infect Dis, 46: 295-298 
Nazik H, Öngen B, Mete B, Aydin S, Yemişen Met al., 2011. Coexistence of blaOXA-48 and aac(6')-Ib-cr genes in Klebsiella pneumoniae isolates from Istanbul, Turkey. J Int Med Res, 39: 1932-1940

Perez FJ and Hanson ND, 2002. Detection of Plasmid-Mediated AmpC $\beta$-Lactamase genes in clinical isolates by using multiplex PCR. J Clin Microbiol, 40: 2153-2162

Perez FJ, Endimiani A, Hujer KM and Bonomo RA, 2007. The continuing challenge of ESBLs. Current Opin Pharmacol, 7: 459-469

Roe MT, Vega E and Pillai SD, 2003. Antimicrobial resistance markers of class 1 and class 2 integron-bearing Escherichia coli from irrigation water and sediments. Emerg Infect Dis, 9: 822-826

Rosengren LB, Waldner CL, Reid-Smith RJ, Checkley SL, Mc Fall ME et al., 2008. Antimicrobial resistance of fecal Escherichia coli isolated from grow-finish pigs in 20 herds in Alberta and Saskatchewan. Canadian J Vet Res, 72: 160-167

Rowe-Magnus DA, Guerout AM and Mazel D, 2002. Bacterial resistance evolution by recruitment of super-integron gene cassettes. Mol Microbiol, 43: 1657-1669

Sahm DF, Thornsberry C, Mayfield DC, Jones ME and Kalowsky JA, 2000. Multi-drug resistant urinary tract isolates of Escherichia coli: prevalence and patient demographics in the United States in 2000. Antimicrob Agents Chemother, 45: 1402-1406

Sasirekha B, Manasa R, Ramya P and Sneha R, 2010. Frequency and antimicrobial sensitivity pattern of extended spectrum $\beta$-lactamases producing E. coli and Klebsiella pneumoniae isolated in a Tertiary Care Hospital Ameen J Med Sci, 3: 265-271

Senthilkumaran K, 2012. Isolation and detection of antimicrobial susceptibility pattern and ESBL production of Escherichia coli in children with gastroenteritis. Intl J Pharmacol Biosci, 3: 32-34

Su J, Shi L, Yang L, Xiao Z, Li Xetal., 2006. Analysis of integrons in clinical isolates of Escherichia coli in China during the last six years. FEMS Microbiol Lett, 254: 75-80

Tadesse DA, Zhao S, Tong E, Ayers S, Singh A et al., 2012. Antimicrobial drug resistance in Escherichia coli from humans and food animals, United States, 1950-2002. Emerg Infect Dis, 18(5): 741-749

Van Essen-Zandbergen A, Smith H, Veldman K and Mevius D, 2007. Occurrence and characteristics of class 1, 2 and 3 integrons in Escherichia coli, Salmonella and Campylobacter spp. in the Netherlands. J Antimicrob Chemother, 59: 746-750

Walsh TR, Toleman MA and Jones RN, 2007. Comment on: occurence, prevalence and genetic environment of CTX-M $\beta$ lactamases in Enterobacteriaceae from Indian hospitals. J Antimicrob Chemother, 59: 799-800

Wani SA, Bhat MA, Samanta I, NishiKawa Y and Buchh AS, 2003. Isolation and 
characterization of Shiga toxin-producing Esherichia coli (STEC) and enteropathogenic Esherichia coli (EPEC) from calves and lambs with diarrhoea in India. Lett Appl Microbiol, 37: 121-127

Weill FX, Demartin M, Tande D, Espie E, Rakotoarivony I et al., 2004. SHV-12-like extended-spectrum-lactamase-producing strains of Salmonella enterica serotypes Babelsberg and Enteritidis isolated in France among infants adopted from Mali. J Clin Microbiol, 42(6): 2432-2437

Winokur PL, Canton R, Casellas JM and Legakis N, 2001. Variations in the prevalence of strains expressing an extended-spectrum $\beta$-lactamase phenotype and characterization of isolates from Europe, the Americas, and the Western Pacific region. Clin Infect Dis, 2: $94-103$

Witte W, 1998. Medical consequences of antibiotic use in agriculture. Science, 279: 996-997

World Health Organization, 2001. Global Strategy for Containment of Antimicrobial Resistance. Publication no. WHO/CDS/ CSR/DRS/2001.2a. Geneva

Zhang HM, Shi L, Li L, Guo SY, Zhang XM et al., 2004. Identification and characterization of class 1 integron resistance gene cassettes among Salmonella strains isolated from healthy humans in China. Microbiol Immunol, 48: 639-645 